\title{
Bonhoeffer in South Africa: role model and prophet
}

\author{
P G J Meiring \\ (University of Pretoria)
}

\section{ABSTRACT}

\section{Bonhoeffer in South Africa: role model and prophet}

Dietrich Bonhoeffer, arguably more than any other European theologian, influenced the way in which South African Christians, clergy and laity alike, have come to see their role in the struggle against apartheid. In his article the author describes the manner in which the German theologian was accepted as a role model by many, and evaluates his influence in the theological and ethical debates in the country. The aim of the article is to determine whether Bonhoeffer - who was born a hundred years ago, in 1906 - still has a message for us today, in a different time and under different circumstances. The author's conclusion is in the affirmative: Bonhoeffer's message is as powerful as ever. The basic principles in his teaching are as important to us today and tomorrow as they have been in the past. The author refers to five principles: 'Confessing Christ here and now', 'Putting a spoke in the wheel', 'Learning to see things from below', 'Acknowledging our guilt', and 'Becoming a church for others beyond privilege'.

\section{INTRODUCTION}

When did Bonhoeffer visit South Africa? He knows our situation from the inside!”

Eberhard Bethge was amused at the question put to him quite innocently by a number of lay Christians who had no previous knowledge of the German theologian, at a Bonhoeffer seminar in Johannesburg in 1973. Back home he remembered the question, and in an essay based on his experience in South Africa he wrote about the many similarities - as well as differences - between Bonhoeffer's Germany and South Africa in the 1970s (De Gruchy 1984:4).

Bonhoeffer indeed never visited South Africa, and he probably did not know a great deal about the country, although he did choose South Africa as background for a novel he wrote in prison toward the end of his life. His choice may have been motivated by his passionate interest in the plight of Blacks in America, or prompted 
by the decision of one of his second cousins to emigrate to South West Africa (Namibia) in 1934. Be that as it may, the relevance of Bonhoeffer for South Africa was never in doubt. John de Gruchy, doyen of modern day Church historians in South Africa, chose Bonhoeffer as partner in dialogue for doing theology in South Africa. He wrote his doctoral thesis on Bonhoeffer, and in the decades that followed devoted many a book and article - as well as numerous lecture series at home and abroad - to Bonhoeffer's continuing relevance to the South African situation. Over the years theologians from all traditions followed De Gruchy's example (1984:2). No less than three Reformed theologians - Johan Botha (1989), Carl Anthonissen (1993) and Russel Bothman (1994) completed doctoral theses devoted to different aspects of the theology and praxis of Dietrich Bonhoeffer.

On a personal note: I was a second year theology student at the University of Pretoria in 1960, when a visiting chaplain addressing a Students' Christian Association conference introduced us to Bonhoeffer, relating the story of his life and death at Flossenbürg, urging us to read Bonhoeffer's The Cost of Discipleship. I did that, with growing admiration and awe - and consternation, because the implications for South African Christians, in our context, was inescapable. To a young Afrikaner hoping to be ordained into the ministry of the white Dutch Reformed Church (DRC), Bonhoeffer's challenge was quite frightening. Reading Bonhoeffer's Letters and Papers from Prison in the months that followed did not help either. The heroism of the prisoner, the messages to his family and friends, the brief - often disturbing - insights into Dietrich Bonhoeffer's thinking, above all his poems, continued to inspire and haunt me. Little did I realise at the time how many fellow South Africans were struggling with the same questions, how profound the effect of Bonhoeffer's theology - as well as his identification with the Barmen Declaration and his role in the struggle of the Confessing Church in Germany - would be on theologians and lay Christians alike, in years to come.

\section{SHARPEVILLE AND COTTESLOE}

The 1960s were difficult and traumatic years in the political as well as ecclesiastical history of South Africa. On March 21, 1960 South Africans - as well as the wider world - were shocked by the news of the Sharpeville massacre. A large number of Blacks protesting 
against the Apartheid Laws of the time, gathered outside a police station near the town of Vereeniging to burn their hated passbooks. The beleaguered policemen opened fire, killing 69, and leaving 180 men and women wounded (Lückhoff 1978:1). The World Council of Churches responded by inviting South African member churches to a consultation at Cottesloe, Johannesburg, in December 1960, to find a way of uniting Christians in the country in their struggle against racism and apartheid. Eberhart Bethge drew an interesting parallel between the correspondence between Geneva and the South African churches and the letters that passed, 30 years earlier, between Geneva and Bonhoeffer as well as between Geneva and the German Evangelical Churches on the very same issues (De Gruchy 1984:3).

Peter Hinchliff who served as Professor of Church History at Rhodes University, Grahamstown, in the 1960s recalls how Bonhoeffer was used by local Christians trying to make sense of the South African context, battling to understand the different options open to them:

One can say of Bonhoeffer at least, that as he understood the nature of sin, it is possible to find oneself in a situation where every course open seems sinful.

In South Africa in the early 1960s that seemed a very obvious truth. It was the aftermath of Sharpeville. The horrors of the political situation was inescapable. One was burdened with a terrible sense of responsibility and guilt for a society of which one could not wash one's hands nor do very much to improve. It was also a period when Bonhoeffer's reputation and influence was at its height. It was hardly possible not to look at one's dilemma (even if only at intuitive level) through his eyes (1983:104f).

The Cottoesloe Consultation was, at best, a limited success. The discussions went remarkably well, and the WCC member churches the English speaking churches as well as the two Afrikaans churches that attended - achieved a remarkable consensus on the Christian witness against racism and apartheid. I was privileged to attend one of the sessions at Cottesloe. My father (the Rev A M Meiring) led the delegation of the Transvaal Synod of the DRC, and he invited me to tag along. I remember the gravity of the discussions, the excitement at finding one another, as well as the apprehension at the 
possible reaction of the churches once the message was released to the public. The strong anti-racist message of Cottesloe was indeed welcomed by many, but caused a furore in Afrikaans church circles. The synods of the DRC who met within months after the consultation, firmly rejected Cottesloe's message - and promptly decided to cut their ties with the WCC (Lückhoff 1978:1ff; 128ff).

\section{THE STRUGGLE FOR A CONFESSING CHURCH}

Beyers Naude, one of the DRC delegates, was deeply disturbed and disappointed at the DRC's stance, and with a number of colleagues decided to establish a Christian Institute of Southern Africa, to continue with the work initiated at Cottesloe, to challenge the Afrikaans churches on the issues of apartheid and racism, and to spearhead a confessing church movement within South Africa. Serious thought was given to the establishment of a Bekennende Kirche (confessing church) as a kind of ultimate Christian political action, placing 'the Church' in stark opposition to government, going underground and virtually courting persecution. The inspiration behind this suggestion was again Bonhoeffer and the events in which he was involved in Germany in the thirties (De Gruchy 1984:4). The Christian Institute was established in 1963 with a membership of 180 clergy and laity, black and white. With Beyers Naudé as its first director and editor of its magazine Pro Veritate, the Institute - until its banning by government order in 1977 - played a valuable role in studying the issues of the day, challenging the Christians in South Africa on their stance against racism and apartheid. During the first years of its existence, Pro Veritate's main source of inspiration was the church struggle in Nazi Germany (Villa-Vicencio \& De Gruchy, 1985:17).

Beyers Naudé paid a heavy price for his role in all of this. After he took leave of his Johannesburg congregation to take up the directorship of the CI, the DRC turned its back on Naudé. His ordination as a minister of the church was cancelled. For the following 25 years he would have a rough ride. His home and office were frequently searched by the police. He was subpoenaed to appear in court. He was arrested and convicted. Eventually he was served with a seven year banning order, effectively silencing his voice in South Africa. But Naudé was not to be ingnored or forgotten. To many, local as well as from overseas, "oom Bey" ("uncle Bey") had become the icon of the struggle, the Bonhoeffer of 
his time, who was willing to consider the cost of discipleship, and committed to paying the price of obedience (cf Naudé 1995:54ff).

During this time, in the late 1960s, the 1970s and early 1980s the quest for a confessing church was actively pursued. The SACC published a Message to the People of South Africa in 1968 which bore remarkable resemblance to the Barmen Declaration of the German Churches. At a press conference to present the document the then General Secretary of the SACC Bishop Bill Burnett put it unequivocally:

The Message asserts with utmost clarity... that the apartheid ideology cannot be squared with the gospel of Jesus Christ... Like the Barmen declaration produced by the German Confessing Church, the Message is a challenge to the conscience of every Christian in terms of the Gospel. This does not mean that the situation in Germany in the thirties is in all respects comparable to present-day South Africa nor does it mean that a confessing church is now inaugurated here. But who can say where the Christian obedience will lead the church in the months and years that lay ahead? We trust in God" (Villa-Vicencio \& De Gruchy 1985:20f).

For the first time an official South African church document declared apartheid to be a false gospel, paving the way for the declaration that apartheid was nothing but a heresy (De Gruchy 1985:21). The Message was followed in years to come by similar statements, the Kairos Document (1985), the Road to Damascus, and eventually by the Belhar Confession of the Uniting Reformed Church of SA (adopted by synod in 1986), each of them offering a strong and inescapable rejection of all forms of racism in church and society. The Afrikaans churches who not only approved of apartheid, but provided a theological argument for it as well, came under increased pressure.

\section{STATUS CONFESSIONIS}

Outside South Africa opposition against apartheid was also mounting, on the continent of Europe as well as in the United Kingdom. More than any other other figure outside South Africa itself, says Keith Clements in a recent study, was it Bonhoeffer's example and theology that was invoked in the involvement of the British churches in the struggle against apartheid (Clements 
2006:143). Eventually, in 1982, the World Alliance of Reformed Churches, meeting in Ottawa, took the historic step of declaring that the apartheid situation in South Africa, and the position of both white South African member churches with reference to it, constitute a status confessionis - meaning, as Ottawa put it, "that we regard this as an issue on which it is not possible to differ without seriously jeopardizing the integrity of our common confession”. There could be no misunderstanding of the severity of the situation: "We declare that... apartheid... is a sin, and that the moral and theological justification of it is a travesty of the gospel, and in its persistent disobedience to the word of God, a theological heresy" (Blei 1994:2).

Once again, the voice of Bonhoeffer could be heard in the background, Bonhoeffer who retrieved the concept of a status confessionis last used in 1550 in the Lutheran Formula of Concord (art. $\mathrm{x}$ ), in discussing the question whether the 'Aryan paragraph', introduced by the Nazi government, might also be applied in the church. To exclude (baptised, Christian) Jews from membership of the church, Bonhoeffer contended, would be a violation of the church in its substance, a denial of God's act of reconciliation in the cross of Jesus Christ, through which he "has broken down the dividing wall between Jews and gentiles" and "made the two into one" (Eph 2:14f). "A church that accepted the Aryan paragraph in its own life, would cease to be the church of Christ. One could serve such a (pseudo) church only by leaving it” (Blei 1994:5). So serious the situation was adjudged, that the membership of the Afrikaans Churches was suspended by the World Alliance, until the day they truly repented of their sin and heresy.

It took a long time before the DRC was able to comply. It did eventually happen at the General Synods of 1990 and 1994, when the delegates bowed in shame before the world, the ecumenical church, their fellow South Africans who suffered over the years, and also before their own members who were, over many years, lead astray by the leadership of the church, confessing their deep regret at the sin and heresy of actions and its theology. Many events lead to this, not in the least the voices and the campaigns of dissenters within the DRC itself who over the years have tried to call the church to task: Ben Marais and Bennie Keet, David Bosch and Nico Smith, Willie Jonker, Jaap Durand, David Botha and many others. In the early 1980s the time had come for a number of actions to be 
taken in the spirit of Barmen and of Bonhoeffer. Eight theological professors produced a Reformation Day Declaration (1980). A book called Stormkompas ("Storm Compass") containing a strong antiapartheid message as well as a list of Barmen-type theses was published (1981). An Open Letter signed by 123 ordained ministers of the DRC pleading with the church to review its policy on apartheid, calling for reconciliation and unity, caused consternation in the ranks of the DRC (1985). Eventually Willie Jonker, respected Stellenbosch theologian, in an address to an ecumenical consultation at Rustenburg (1986), courageously offered a confession of guilt for the sins of his church, especially for its complicity in apartheid. It was a moment of intense emotion. Desmond Tutu who chaired the session was deeply touched, and accepted Jonker's confession (De Gruchy 1997:362).

The table was set for the DRC to officially follow suit. It happened, as stated above, at the 1990 Synod, and again at the Pretoria Synod of 1994. The delegates reiterated their confession, asking forgiveness as well from the prophets within the church whose voices were ignored over the years, who were shunned and often ostracized. There were moments never to forget. The aging professor Ben Marais was given a standing ovation. And on the final day when Beyers Naudé arrived at synod, he too received a standing ovation, led by Johan Heyns (who years ago chaired the commission that stripped oom Bey of his ordination). Serving as Director of Ecumenical Affairs of the DRC, I accompanied oom Bey to his seat. His eyes were brimming with tears: "Piet", he said, "the circle is complete. My church and my people have received me back in their fold. I praise the Lord for this day!”

Bonhoeffer's life, sadly, ended on a different note.

\section{BLACK THEOLOGY AND LIBERATION THEOLOGY}

Thus far the story of Bonhoeffer's influence on events and developments in main line Christianity in South Africa. But that is only half the story. In the 1960 and 1970s a new theological wave swept over South Africa: that of black theology and liberation theology. It happened in Latin America, in the USA and it happened in South Africa. The names of Desmond Tutu, Allan Boesak, Frank Chikane, Manas Buthelezi, Simon Maimela, Barney Pityana and Buti Thlagale, among others, appeared in the headlines of church and secular publications. They brought with them a new brand of 
theology, a theology geared to the needs of the time, in answer to the questions raised by their people, the poor and the marginalized; geared to the angry voices of those who struggled against their oppressors.

In all of this Bonhoeffer's influence was profound. Although there may be no direct causal link between Latin American Theology of Liberation and Bonhoeffer, Julio de Santa Ana once wrote, liberation theology can not be explained apart from his influence (1976:188f). The same is true of many Third World countries where Dietrich Bonhoeffer was held in high esteem and it is certainly true of South Africa where Bonhoeffer's impact on liberation theologies and contextual theologies is stronger than that of any other $20^{\text {th }}$ century theologian (De Gruchy 1984:4).

It became obvious with the publication of the Kairos Document of 1986, that the theological map had changed drastically. Reminiscent of Bonhoeffer's blunt distinction between the true and the false church, the Kairos Document declared that the time had come for Christians to choose sides, to join the resistance. It was not enough to reject apartheid in principle and yet stop short of political solidarity with the liberation struggle. The moment has arrived for the church to stand with the oppressed in their struggle for justice and freedom. There could be no cheap reconciliation. What was needed was, in Bonhoeffer's words, costly grace (The Kairos Document, 1986).

Among white Christians, responding to the challenge of Black Theology and Liberation Theology, the issues of civil disobedience and conscientious objection to military service defending "an unjust war”, was hotly debated. A handful of young men courageously elected to go to prison, rather than serving in the army, or in the army chaplaincy. Bonhoeffer's metaphor about "putting a spoke in the wheel" of the Nazi state (from his 1933 essay on The Jewish Question) began to make a lot of sense to them. Of course the issues were ambiguous. Bonhoeffer's reluctant involvement in the conspiracy against Hitler did raise questions. Bonhoeffer knew only too well that even a "just war" was still a war with all its awful consequences. But Bonhoeffer confronted his South African colleagues with the example of someone who, in following Christ, made a personally costly decision that doing nothing to rid the world of Hitler was worse than doing what he did, however ambiguous the 
moral issues. That is what peacemaking demanded of him at that time and place. In making that decision he could only "sin boldly" and cast himself on the grace of God (De Gruchy 1997:3, cf Bethge 1995:30ff).

Bonhoeffer's inspiration also reached non-theologians in the struggle. Similarities were often indicated. Mandela's famous Speech from the Dock before his conviction and imprisonment was compared to Bonhoeffer's essay on The Structure of Responsible Life. And when Steve Biko, foremost spokesperson of the Black Consiousness Movement died at the hands of policemen, his death was immediately compared with that of Bonhoeffer.

\section{BONHOEFFER AND THE NEW SOUTH AFRICA: “ARE WE STILL OF ANY USE?”}

Is Bonhoeffer's message still relevant to us today? Does the 'troubling witness' (as John de Gruchy refers to him) speak to us in the complex and often 'troubling' times that we in South Africa are facing today? And his many protagonists among the scholars and the laity - does Bonhoeffer who died more that sixty years ago, provide them, and us, with a message for tomorrow?

"Are we still of any use?" was the theme for the Seventh International Bonhoeffer Congress, held in Cape Town in January 1996, where delegates from many countries convened, to find answers to the above questions for South Africa, as well as for the countries they hailed from. There was no dissent about the impact of Bonhoeffer's life and thought on the ecumenical church since his martyr's death in Berlin more than sixty years ago. But was his message as clear and significant at the beginning of the $21^{\text {st }}$ century, in our rapidly changing world?

The theme question came from the last line of an evocative essay After Ten Years that Bonhoeffer sent as a Christmas gift to his brother-in-law Hans von Dohnanyi and his two close friends Hans Oster and Eberhard Bethge in 1942. Reflecting on their many struggles during the previous years and the difficult, sometimes morally ambiguous decisions they had to take, Bonhoeffer wrote:

We have been silent witnesses of evil deeds; we have been drenched by many storms; we have learnt the arts of equivocation and pretense; experience has made us suspicious of others and kept us from being truthful and 
open; intolerable conflicts have worn us down and even

made us cynical. Are we still of any use? (Letters, 16)

The delegates identified with Bonhoeffer's position. The socially privileged and academically trained (mostly, white) delegates were still agonizing about their role in the liberation struggle, about their often timid response to the atrocities of the past. Among the comrades (mostly, blacks) who have been actively engaged in the fighting, were those who also knew about employing decisions that were sometimes morally ambiguous, about tactics that were ethically unacceptable, and actions that in time had to be brought to the Truth and Reconciliation Commission. To both groups, Bonhoeffer's example and theology provided inspiration. Many testified of being 'liberated' by his message. But that was of the past. The question now was to all Bonhoeffer scholars and followers: are we still of any use today?

The answer at the conference was a resounding "Yes". Bonhoeffer's message is as powerful as ever. Five basic principles in his theology are as important to us today and tomorrow as they have been in the past.

\subsection{Confessing Christ here and now}

As important as it was for the Confessing Church (Bekennende Kirche) in Nazi-Germany to confess its allegiance to Jesus Christ alone over and against the false gods and ideologies of the time; as crucial it was for South African Christians to, in the name of Jesus Christ their Lord, call for a status confessionis against the heresy of apartheid; so important the challenge remains for Christians in this country - as indeed in every country - to raise the banner of Christ in every new situation, facing every new heresy and ideology that may arise in the future. Christians in six continents are called to be 'troubling witnesses', in society (Clements 2006:143). It does not come easy, and it does not come cheap. It comes at a price, Bonhoeffer warned, placing his own life on the altar. But this is what we need: men and women who in the mold of Dietrich Bonhoeffer or Beyers Naudé, are still willing to consider the cost of discipleship, confessing Christ in every sphere of life, in every situation they face. Bonhoeffer's concern in 1932 needs to be ours today:

In all that we say and do we are concerned with nothing but Christ and his honour among men. Let no one think that we are concerned with our own cause, with a 
particular view of the world, a definitive theology or even with the honour of the church. We are concerned with Christ and nothing else. Let Christ be Christ (De Gruchy 1984:11).

\subsection{Putting a spoke in the wheel}

When the Confessing Church in the 1930s did not rise to Bonhoeffer's expectations, when Barmen failed to speak out against the persecution of the Jews in the Third Reich, Bonhoeffer decided to move outside the parameters of the Bekennende Kirche, to involve himself in the resistance, ultimately to involve himself in a plot against Hitler. Already in his Essay on the Jewish Question in 1933 he recognized that the time may come that - if the state utterly failed in its duty to provide for and protect a just order - it may become necessary to "put a spoke in the wheel", to choose the way of active resistance. During the years of apartheid Bonhoeffer's stance was welcomed and emulated by many South Africans. The Kairos theologians openly identified with the armed struggle. The question now is: How should this "Kairos theology" inform our praxis in South Africa in the future, if human rights deteriorate, if justice for all comes under threat - as has happened in a number of African countries. "Where are the Kairos theologians"?, De Gruchy asked at the Cape Town Conference. "Are those who signed the Kairos Document still of any use?” (1997:359)

\subsection{Learning to see things from below}

Bonhoeffer's perennial challenge to the Christians of his day was to learn to see things from below, from the perspective of those who suffer. While visiting New York in 1930 he was appalled at the plight of the African Americans, and identified with their struggle for recognition and justice (Clements 2006:2f). Back in Germany he courageously identified with the Jewish community, with the victims of the Holocaust. In the South African context his legacy had a particular impact on a generation of privileged white believers, challenging them to listen to the voices of their black compatriots, to recognize the legitimacy of their struggle for liberation, and eventually, to identify with the struggle.

Solidarity, sharing in the suffering of others, does not come easy, John de Gruchy (1997:360) reflecting on the South African experience, reminds us: 
Martyrdom is not, in any case, something which one chooses, even though it is sometimes the consequence of solidarity, as we know in our context, which has been so terrifyingly rich in martyrs. But even if not all suffer to the same extent, all are called to learn to see things from this perspective and to act accordingly. This is the call to costly discipleship, a lifelong journey of learning, a journey full of temptations, failures, and yet joys, victories, and celebrations.

Learning to see from below, Bonhoeffer insisted, implies the acceptance of one's responsibility. In some cases it is the responsibility of resistance, but in all cases it is the responsibility of service in solidarity with others. In South Africa at this time of healing and reconciliation, of political, social and economic reconstruction, it implies that nobody should shirk their responsibility - not the whites who have been privileged in so many ways in the past, but who are tempted to withdraw from public responsibility to pursue the goals of self-interest. The same applies to the new elites of the South African society, those who were powerless but have become powerful; those who were in solidarity with the poor, but who are fast becoming numbered among the rich (De Gruchy 1997:361).

\subsection{Acknowledging our guilt}

Dietrich Bonhoeffer, in his doctoral thesis (Sanctorum Communio) as well as in his Ethics challenged the church to lead the nation in dealing with the past. He was disappointed with the Confessing Church's failure to live up to its early promise, and insisted that the church should confess both its own guilt and that of the nation for the sake of its rebirth and renewal. This did not happen during his lifetime. It was only after the war, in 1945, that the Evangelical Church published their Stuttgart Confession of Guilt.

The role of the South Africa churches in leading the nation in the confession of our collective guilt, was as hotly debated as in Germany in the 1930s. For the Afrikaans Dutch Reformed Church as we have seen above - the time did come in the 1990s, when the church which not only happily lived with apartheid over the years, but provided a theology of separate development to go with it, confessed its shame and guilt, asking forgiveness of its fellow South Africans who had suffered over so many years, as well as of the 
'prophets inside and outside the fold of the church' who warned against apartheid and were treated shoddily. Lastly, the church asked forgiveness of its own members who were lead astray over the years.

Some years later (1997) all the faith communities in South Africa were invited to a special hearing of the Truth and Reconciliation Commission, to reflect on their past: not only on the way they suffered from and struggled against apartheid, but also on the overt and covert support of apartheid and discrimination from within their own ranks. The vast majority of churches as well as other faith communities used the opportunity to try and understand their own past, defining and identifying with their guilt, asking for forgiveness from the nation, as well as from one another. I was privileged to attend the hearing in East London, and am still inspired by the event, which was hailed by Archbishop Desmond Tutu as "probably the best of all the Truth Commission hearings" (Meiring 1999:265). Eighteen months later, after the Report of the TRC was published, the chair (Archbishop Tutu) and the vice-chair (Alex Boraine), significantly were invited to receive the Dietrich Bonhoeffer prize in the French Cathedral, Berlin (25 April 1999).

This however does not mean that the process is finished. Far from it! Not all churches attended the TRC hearing. Their voices need still to be heard. Many white Christians to this day do not see the need for confession or mistrust the process. Some blacks have become disappointed and cynical. Recent events in South Africa illustrate how much still has to be done in terms of national healing and reconciliation. It was one thing to delete apartheid from the statutes of government, but to erase it from the minds and hearts of the people may take a very long time. Bonhoeffer's challenge to the churches to continue with the process of confession, to lead their members to reach out to one another - asking for and granting forgiveness - is as relevant as ever.

\subsection{Becoming a church for others beyond privilege}

Bonhoeffer was, according to David Bosch (1991:375), the architect of the perception of the church as 'the church for others'. The words that he wrote from the Nazi prison in 1944 resounded across the world: "The church is the church only when it exists for others... The church must share in the secular problems of ordinary human life, not dominating, but helping and serving” (1971:382). Years later Charles West (1971:262) and Theo Sundermeier alterted us to the 
fact that Bonhoeffer's phrase was coined from the typical liberalhumanist bourgeois climate in which Bonhoeffer had grown up, particularly the idea that Western Christians know what is best for others and, hence, they tend to proclaim themselves guardians for others. Instead of talking about "the church for others", we should rather speak of "the church with others", Sundermeier argued (1986:62ff).

Be it as it may, Bonhoeffer's insights into the nature and the calling of the church within a post-Christendom secular society are of great importance to us as we begin to re-evaluate the role of the church and of the Christian faith in a new democratic multi-faith and multi-cultural South Africa. It goes without saying that Bonhoeffer's insights need to be reinterpreted in our time. His expectations of "a world come of age" where people come to live "as if there were no God" (esti Deus non daretur) were not fully realized (Bosch 1991:270). It may be true of secularized Western Europe, but it is not true of many other countries in the world, and it is definitely not the case in South Africa. De Gruchy (1997:363) comments:

One the one hand, of course, we are rapidly shedding our Constantinian heritage and becoming a secular society; on the other hand we remain a very religious society, though now more fully aware than before of the multifaith dimension of this religious character.

...This has raised the question as to whether Bonhoeffer's theology, not just that of the church struggle period, but even of the prison letters, is still of any use to us in South Africa. We are no longer engaged in a church struggle in the way we were, and our society is by no means a religionless one.

Yet if we properly understand what Bonhoeffer meant when he spoke about the church as church for others, a church that emulates its Lord who came to serve, who knelt down to wash the feet of his disciples, we have some inkling of what it means to be the church of Jesus Christ in South Africa today. In a society still ravaged by pain and suffering, reeling under corruption, violent crime, the HIV/AIDS pandemic, where millions are still poor and unemployed, and where women are still fighting for proper recognition, being the "church for others" is an inescapable obligation, but it comes at no easy cost. It calls for real commitment, to Christ and to the world, for a rediscovery of the ancient disciplina arcani, for true spirituality and 
prayer to guide our actions (De Gruchy 1997:364, cf Bosch 1991:514f).

This brings me back to the first encounter I - together with many other South Africans - had with Dietrich Bonhoeffer, the author of the Cost of Discipleship, fourty years ago: the martyr in Tegel prison with his pen in hand, the prophet and the hero. I am still in awe of his example, still encouraged by his joy in spite of moments of darkness of the soul, and of his total commitment to the Lord he served, even to the point of sharing his cross. I hear him whisper: Never lose hope, never give in to despair:

It may be that the day of judgement will dawn tomorrow; in that case, we shall stop working for a better future. But not before (quoted by De Gruchy 1984:1).

But above all I hear him sing, as in the very last lines of his poem Wer bin Ich ("Who am I?") in which he describes the many roles awarded to him by his fellow inmates and the wardens, as well as his varying emotions, his hope and his despair, in his lonely cell. "Who am I?", he asks, and then provides the answer himself, an answer that echoes through time:

"Who am I? They mock me, these lonely questions of mine,

Whoever I am, Thou knowest, O God, I am thine!” (Bonhoeffer, 1953:126)

\section{Consulted literature}

Anthonissen, C 1993. Die geloofwaardighedi van die kerk in die teologie van Dietrich Bonhoeffer. Doctoral thesis: University of Stellenbosch.

Bethge, E 1995. Friendship and resistance. Essays on Dietrich Bonhoeffer. WCC: Geneva/Grand Rapids: Eerdmans.

Blei, K 1994. Apartheid as a status confessionis. Geneva: WARC, Semper Reformanda.

Bonhoeffer, D 1960. The cost of discipleship. New York: Macmillan.

-, 1965. Ethics. New York: Macmillan.

-, 1953. Letters and papers from prison (abridged edition). London: SCM Press.

-, 1972. Letters and papers from prison (enlarged edition). New York: Macmillan. 
Bosch, D J 1991. Transforming Mission. Paradigm shifts in Theology of Mission. Maryknoll: Orbis.

Botha, J G 1989. Skuldbelydenis en plaasbekleding. ' $n$ Sistematiese Teologiese ondersoek na die rol van die skuldvraag in die denke en praxis van Dietrich Bonhoeffer, tussen die jare 1924 en 1945. Doctoral thesis: University of Western Cape.

Botman, R 1994. Theology as transformation? Towards a Theology of Transformation. Doctoral thesis: University of Western Cape.

Clements, K 2006. Bonhoeffer and Britain. London: Churches Together in Britain and Ireland.

De Gruchy, J W 1979. The Church Struggle in South Africa. Cape Town: David Philip.

-, 1984. Bonhoeffer and South Africa. Theology in Dialogue. Grand Rapids: Eerdmans.

-, (ed) 1997. Bonhoeffer for a new day. Theology in a time of transition. Grand Rapids: Eerdmans.

-, (ed) 1999. The Cambridge Companion to Dietrich Bonhoeffer. Cambridge: University Press.

De Santa Ana, J 1976. "The Influence of Bonhoeffer on the Theology of Liberation”, Ecumenical Review 28 1976, $188 \mathrm{f}$.

Hinchliff, P 1983. Holiness and Politics. Grand Rapids: Eerdmans.

Lückhoff, A H 1978. Cottesloe. Kaapstad: Tafelberg.

Meiring, P G J (Piet) 1999. Chronicle of the Truth Commission. Vanderbijlpark: Carpe Diem.

Naudé, B 1995. My land van hoop. Cape Town: Human en Rousseau.

Sundermeier, T 1986. Konvivenz als Grundstruktur ökomenischer Existenz heute. Ökumenisch Existenz Heute, 49-100.

Villa-Vicencio C, and De Gruchy, J W (eds) 1985. Resistance and hope. Essays in honour of Beyers Naudé. Cape Town: David Philip/Grand Rapids: Eerdmans.

West, C 1971. The power to be human: Toward a secular theology. New York: Macmillan. 